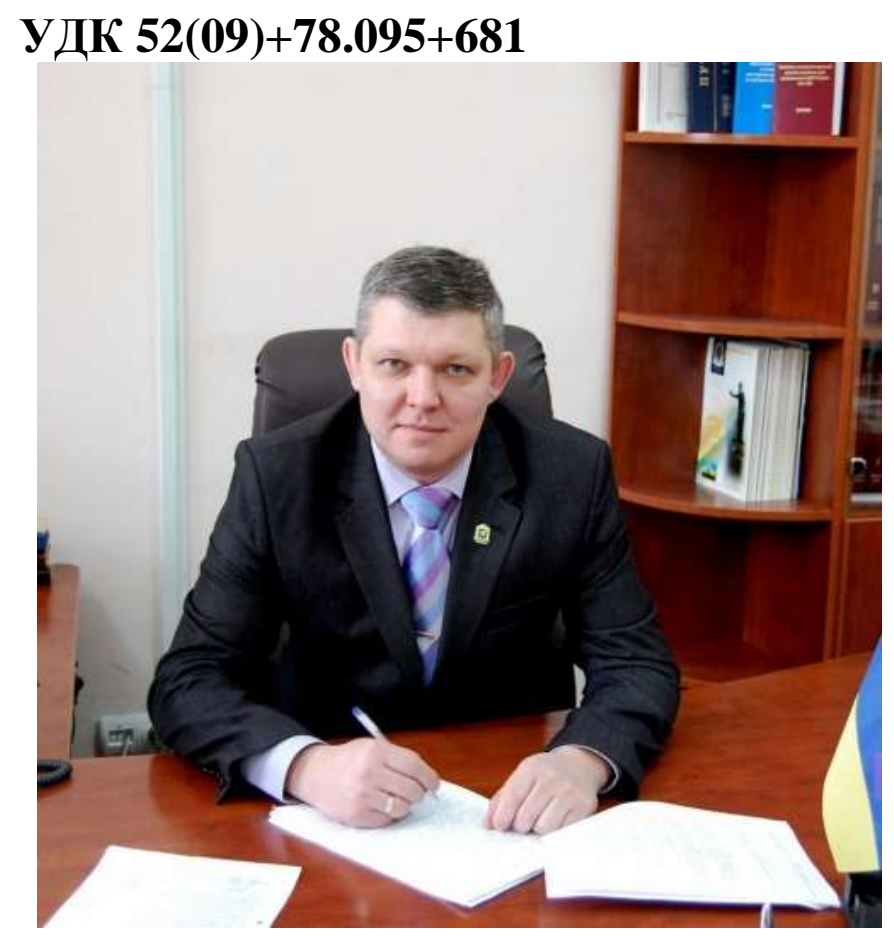

\title{
БАЛИШЕВ Марат
}

кандидат історичних наук, директор Центрального державного науковотехнічного архіву України

(м. Харків, Україна)

\section{m.a.balyshev@gmail.com}

\section{СТВОРЕННЯ ТА ДІЯЛЬНІСТЬ ШКОЛИ-МАЙСТЕРНІ ТОЧНОЇ МЕХАНІКИ ХАРКІВСЬКОГО УНІВЕРСИТЕТУ (1915-1919)}

У запропонованому дослідженні реконструйовано основні етапи, пройдені Школою-майстернею точної механіки Харківського університету в прочесі їі створення та становлення, як учбового закладу у 1915-1919 рр. Розглянуто передумови, мету та принципи створення Школи-майстерні; формування тематики та напрямів ї̈ навчальних програм; техніко-економічне обтрунтування діяльності Школи-майстерні; формування учбововикладацького складу та створення інструментальної бази; з'ясовано причини припинення ї̈ діяльності. Архівні документи, які вперше були залучені до розгляду, дозволили відтворити хронологічну послідовність у розвитку подій, пов'язаних із функиіонуванням Школи-майстерні точної механіки, довести (або уточнити) деякі маловідомі факти.

Висвітлено внесок проф. Л. О. Струве в організаційний проєкт зі створення та розвитку Школи-майстерні; визначено його вплив на формування напрямів ї̈ роботи, навчальний прочес та виробничі завдання, зокрема, спрямовані на виконання замовлень Харківського військовопромислового комітету; встановлено взаємозв'язки між навчальним закладом та Харківською астрономічною обсерваторією; розглянуто участь харківських астрономів у роботах Школи-майстерні. Досліджено питання щзодо виділення Харківським університетом земельної ділянки під спорудження власної будівлі Школи-майстерні та розробку ї̈ проєкту університетським архітектором.

Автором застосовано спеціальні методи дослідження (історикохронологічний, ретроспективний та методи джерелознавчого аналізу), використання яких дозволило з'ясувати особливості функціонування Школимайстерні у визначений період. 
Передбачається, щзо матеріали історико-наукового дослідження щзодо створення та діяльності Школи-майстерні у 1910-х роках будуть використані y науково-дослідній роботі, присвяченій історії астрономії у Харкові першої половини $X X \mathrm{~cm}$.

Ключові слова: Школа-майстерня точної механіки, Харківська астрономічна обсерваторія, Л. О. Струве, механічні роботи, інструментальна база, промислові училищуа, фізико-математичний факультет Харківського університету

\section{THE ESTABLISHMENT AND ACTIVITY OF THE SCHOOL-WORKSHOP OF PRECISION MECHANICS OF THE KHARKIV UNIVERSITY (1915-}

1919)

The proposed study reconstructs the main stages of the creation and development processes of School-workshop of precision mechanics of Kharkiv University as an educational institution in 1915-1919. The preconditions, purposes and principles of the creation of educational institution are considered; and also the formation of topics and directions of educational programs; feasibility study of the School-workshop activity; the formation of teaching staff and the creation of tool base; the reasons for termination its activities were clarified. The archival documents, which were first involved in the review, made it possible to recreate the chronological sequence of events, related to the functioning of the School-workshop of precision mechanics and to prove (or clarify) some unknown facts. It was considered the contribution of Prof. Ludwig Struve in the creation and development of the School-workshop; its influence on the formation of the directions of its work, educational process and production tasks, in particular, the fulfilling the orders of the Kharkiv military-industrial committee; the participation of Kharkiv astronomers in the work of the School-workshop; the correlation between this educational institution and the Kharkiv Astronomical Observatory was shown. It was analyzed the issue of allocating an area for the construction of the Kharkiv University's own School-workshop building and the development of its project by an university architect.

The author used special research methods (historical-chronological, retrospective and methods of source analysis), their application allowed to clarify the features of the School-workshop functioning in a certain period. It is assumed that the materials of the historical and scientific research on the creation and the activity of the School-workshop in the 1910s will be used in the research work devoted to the history of astronomy in Kharkiv the first half of the XXth century.

Keywords: School-workshop of precision mechanics, Kharkiv Astronomical Observatory, Ludwig Struve, mechanical works, tool base, industrial colleges, faculty of physics and mathematics of the Kharkiv University

Наприкінці XIX ст., зважаючи на значний попит у суспільстві, у Західній Європі масово виникають годинникові школи та школи точної механіки, 
орієнтовані на виготовлення точних механізмів, слабкострумових електричних пристроїв та виховання майстрів відповідних спеціальностей. У Російській імперії також було здійснено декілька спроб організації відповідних навчальних закладів. Зокрема, у 1900 р. рішенням Державної ради міністрів Російської імперії у складі Ремісничого училища Цесаревича Миколи Міністерства торгівлі та промисловості (Санкт-Петербург) було започатковано Механікооптичне та годинникове відділення.

Взагалі на початку XX ст. потребу у професійних механіках, які займалися конструюванням та налагодженням наукових інструментів, особливо гостро відчували російські університети: для виконання точних робіт майстрів часто «виписували» із-за кордону. Розвиток науки та освіти, які вимагали, перш за все, наочності під час доведення реальності фактів, зростаючий попит на точні наукові прилади і навчальні посібники, - задовольняли в основному за рахунок імпорту. За свідченням університетських професорів, подібна залежність вищої школи від імпортних інструментів дуже негативно впливала на якість учбового процесу, тому, найчастіше, навіть при незначних ремонтах, старі прилади доводилося відправляти за кордон, втрачаючи час та гроші.

Проведений історіографічний аналіз свідчить, що темі створення та розвитку Школи-майстерні точної механіки при фізико-математичному факультеті Харківського університету у 1910-х роках не присвячено окремих історико-наукових досліджень. Деякі факти, пов'язані із функціонуванням Школи-майстерні у зазначений період згадуються мимохідь в історичному нарисі «Астрономія в Харківському університеті за 150 років» (1955) [1]; у колективній праці «200 років астрономії в Харківському університеті» (2008) [2]; у монографії «Отто Людвигович Струве (1897-1963)» (2008), присвяченій життю та творчості видатного американського астрофізика, який народився у Харкові та безпосередньо працював як викладач у Школі-майстерні [3].

Вищенаведене дозволяє дійти висновку, що обрана тема не знайшла належного повного відтворення у дослідженнях з історії науки. Тому існує нагальна необхідність у висвітленні фактів до історії функціонування Школи- 
майстерні точної механіки у Харкові через вивчення архівних документів, які вперше вводяться до наукового обігу.

Зважаючи на викладене, метою роботи $є$ узагальнення результатів проведеного історико-наукового дослідження створення та становлення як навчального закладу Школи-майстерні точної механіки при фізикоматематичному факультеті Харківського університету у 1910-х роках.

Для вирішення конкретно-проблемних завдань у роботі використані спеціальні методи - історико-хронологічний, ретроспективний та методи джерелознавчого аналізу. Джерельну базу дослідження склали матеріали 3 фондів архіву Науково-дослідного інституту астрономії ХНУ імені В. Н. Каразіна [4].

За різних обставин у Російській імперії підготовка відповідних кваліфікованих майстрів, здатних виготовляти для широкого вжитку спеціальні прилади та інструменти, необхідні в учбовому процесі при викладанні фізикоматематичних та природничих наук, не набула системного розвитку. Особливо гостро цю проблему відчували астрономічні обсерваторії, які майже повністю були залежними від інструментарію, виробленого у Європі.

До того ж, все значно ускладнили події 1914-го р., коли з початком Першої світової війни припинився вільний доступ до європейських ринків інструментів. Це миттєво зрозуміли не тільки у вищій, але й у середній школі. Таким чином, склалися об'єктивні передумови до негайного виправлення існуючого положення, яке б дозволяло університетам i обсерваторіям створювати (і ремонтувати) свої інструментальні бази за рахунок вітчизняних ресурсів.

У 1914 р. Н. Б. Завадський (1862-1943), майстер Механіко-оптичного та годинникового відділення Ремісничого училища Цесаревича Миколи запропонував ідею створення Технікуму точної механіки, оптики, часових справ та дрібно-механічних виробництв у Петербурзі (iі було реалізовано у 1921 р.). Додамо, що серед іншого Механіко-оптичне та годинникове відділення виготовляло прилади для Головної фізичної обсерваторії та 
санітарного відділу Центрального Військово-промислового комітету. У 1917 р. на базі відділення було створено самостійне Технічне училище.

3 огляду на ситуацію, декан фізико-математичного факультету Харківського університету проф. Л. О. Струве (1858-1920), представник всесвітньовідомої астрономічної династії Струве [5], пропонує створити майстерню і школу для підготовки професійних майстрів, які задовольняли б потреби у наукових приладах та виконували їх гарантійне обслуговування у Харкові.

Наприкінці 1914 p. фізико-математичний факультет Харківського університету ініціював питання про створення при ньому окремого закладу Школи-майстерні для виготовлення точних наукових приладів, навчальних посібників і підготовки спеціалістів з точної механіки. На думку факультетської професури, яка підтримала пропозицію проф. Л. О. Струве, створення подібного навчального закладу не тільки остаточно зняло б питання відносно придбання нових інструментів і відновлення старих, а й істотно заощадило б витрати університету, зважаючи на комерційні інтереси торгових підприємств. Для забезпечення життєдіяльності розвитку Школи пропонувалося створити наукову раду як вищий орган установи, а вирішення професійно-технічних завдань - покласти на досвідченого механіка [4].

Проєкт організації Школи-майстерні був орієнтований на такий процес навчання: упродовж двох років учні зобов'язані відвідувати загальноосвітні предмети (для отримання знань, необхідних кожному механіку); паралельно працювати у майстернях. Після закінчення дворічного загального курсу вони мали там же підвищувати свою робочу кваліфікацію ще протягом двох років, після чого завершували навчання у Школі [6].

У травні 1915 р. на фізико-математичному факультеті було обрано комісію, до якої увійшли: проф. М. Ф. Бєлоусов, проф. М. М. Євдокимов (18681941), проф. Д. А. Рожанський (1882-1936), проф. М. М. Салтиков (1872-1961), проф. Л. О. Струве, приват-доцент С. С. Хотинський (1877-1959) і механік університетської обсерваторії В.М.Дерев'янко (1857-1920). Перед комісією було поставлено завдання з розробки проєкту статуту і підготовки детального 
кошторису для організації Школи-майстерні точної механіки. Додамо, що у роботі комісії активну участь також взяли - голова Вченого комітету Міністерства народної просвіти проф. Г. В. Левицький (1852-1917), який спеціально прибув до Харкова 3 Петрограда 3 цією метою, та ректор Харківського університету І. В. Нетушил (1850-1928) [4].

До кінця серпня 1915 р. комісія завершила свою роботу і 3 вересня Рада університету ухвалила звернення до Міністерства народної просвіти 3 клопотанням про надання дозволу на відкриття Школи-майстерні, а також виділення відповідних коштів на її облаштування [4].

У жовтні Відділ промислових училищ Міністерства народної просвіти надав позитивну відповідь - клопотання університету було підтримано і задоволено. За попередніми розрахунками, щорічне фінансування Школи встановлювалося на рівні 15 тис. карб. Також одноразово виділялося 59500 крб. на створення інструментальної бази і зведення власного будинку, у якому, крім приміщень для майстерень і навчальних занять, планувалося розміщення квартир для службового персоналу. Ділянку під зведення будівлі передбачалося відвести на межі так званої Університетської садиби (неподалік від астрономічної обсерваторії) [4].

Після отримання погодження від Міністерства, фізико-математичний факультет обирає керівником Школи проф. Л. О. Струве (завідувач обирався на три роки). Також, згідно з п. 13 статуту Школи, було обрано п'ять наукових співробітників, фахівців у різних галузях наук; основним завданням для них була участь в обговоренні нових конструкцій приладів, перевірці та прийманні всіх виробів, виготовлених у майстерні. Точність і якість готової продукції Школи-майстерні гарантувалися їх підписами [7, с. 6].

Наукові співробітники обиралися фізико-математичним факультетом терміном на два роки із числа викладачів Харківського університету «або з кола осіб з вищою освітою, відомих своїм досвідом у галузі технічного викладання або виготовлення наукових приладів» [4]. У 1915 р. такими науковими співробітниками стали: проф. М. Ф. Бєлоусов (фізіологія), проф. М. М. Свдокимов (астрономія), проф. Ю. Д. Слісафов (хімія), проф. А. В. Желеховський (1882- 
1943) (фізика), інженер-технолог Харківського Технологічного Інституту Г. О. Латишев (машини та механічні технології). Додамо, що через кілька місяців проф. Ю. Д. Слісафова змінив проф. І. С. Телетов (1878-1947) (хімія) [4].

Також факультет призначив Раду Школи, яка складалася: із завідувача (який був головою наукових співробітників), головного механіка і викладачів Школи. Згідно зі статутом, на головного механіка покладалося керівництво шкільними майстернями. Кандидат на цю посаду повинен був мати вищу технічну освіту і досвід робіт у галузі точної механіки. До його функцій входило: приймання замовлень, виробництво та отримання платні за готові вироби [4].

Фізико-математичний факультет обрав головним механіком Школи В. М. Дерев'янка, механіка астрономічної обсерваторії Харківського університету; призначив склад Ради від викладачів Школи: Закону Божого протоієрея О. І. Іннокова (священика Антонієвської (університетської) церкви); 3 російської мови - А. І. Адріанова (викладача Маріїнської жіночої гімназії і Першої приватної чоловічої гімназії С. В. Старкова (допоміжного обчислювача астрономічної обсерваторії); 3 фізики - П. М. Єрохіна (приват-доцента Харківського університету і викладача приватної чоловічої гімназії «Товариства другої групи викладачів» М. М. Кноррінга); $з$ технологій і креслення - К. М. Урсу (інженера-технолога, викладача Харківського Технологічного Інституту); 3 малювання I. Ф. Богданова (викладача приватної чоловічої гімназії «Товариства другої групи викладачів» М. М. Кноррінга). Практичними роботами у Школімайстерні керував майстер О.С. Салигін (1882-1953). Усіх викладачів було затверджено Попечителем Харківського навчального округу проф. О. Л. Корольковим (1859-1931) [4].

3 огляду на актуальність і гостроту нагальних проблем, майстерня Школи розпочала функціонувати вже у листопаді 1915 р. (до офіційного відкриття закладу), виконуючи невеличкі ремонтні роботи. Під керівництвом В. М. Дерев'янка працювали два майстри, через рік у Школі працювало вже чотири майстри [4]. 
Однак, восени 1915 р. на утримання Школи у поточному році і придбання інструментів Міністерством народної просвіти виділило тільки 5 тис. крб., а на 1916 р. - відкрили фінансування в обсязі 13 тис. крб. Відсутність коштів на оснащення Школи необхідними інструментами та устаткуванням пояснювалася Міністерством за «неможливістю придбання необхідних інструментів на європейському ринку» [4]. 3 цієї причини у майстерні Школи використовувалися інструменти і б/у верстати, придбані у приватній майстерні В. М. Дерев'янка (асигнувань вистачило на придбання лише одного нового верстата і дрібного інструментарію).

Офіційною датою відкриття Школи-майстерні стало 10 січня 1916 р.; навчання тут було безкоштовним. Перед початком занять у присутності Попечителя Харківського навчального округу проф. О. Л. Королькова, проректора університету проф. М. І. Палієнка (1869-1937), професорів фізикоматематичного факультету, членів Ради Школи-майстерні, майстрів та учнів був відслужений молебень [4].

Школа відкрилася лише з одним молодшим класом; влітку 1916 р. було відкрито другий клас. До завершення першого навчального року у Школі налічувалося 26 учнів (15 - у першому; 11 - у другому класах). У першій половині 1916 р. механічними роботами учнів керував В. М. Дерев'янко, з осені - його учень, інструктор-викладач О. С. Салигін [4].

Упродовж першого року навчання під його керівництвом учні займалися виготовленням різних плоских і просторових фігур з дроту і заліза, при цьому вони також власноруч виготовляли необхідні слюсарні інструменти. На верстаті виточувалися дерев'яні фігури - циліндри, конуси, кулі. Кращі учні залучалися до виконання замовлень Харківського військово-промислового комітету; один учень - спеціально навчався мистецтву шліфування скляних труб для виготовлення точних рівнів [4].

У червні 1916 р. посаду викладача математики (замість мобілізованого до армії С. В. Старкова) зайняв К. Г. Гінце (1885-1922) (асистент астрономічної обсерваторії і викладач приватної чоловічої гімназії баронеси Н. М. Вітте). 3 серпня 1916 р. замість викладача І. Ф. Богданова - призначено відомого 
харківського художника Е. А. Штейнберга (1882-1935), також викладача приватної чоловічої гімназії «Товариства другої групи викладачів» М. М. Кноррінга) [4].

Для потреб Школи-майстерні було відведено частину приміщення у механічній майстерні астрономічної обсерваторії. За Статутом (затверджений Попечителем Харківського навчального округу 31 травня 1916 р.) [7], курс навчання у Школі був чотирирічним, а щорічний прийом становив 20 осіб. Але навіть для учнів, які навчалися у перших двох класах, приміщення майстерні виявилося тісним. Тому викладання загальноосвітніх дисциплін (Закону Божого, російської мови та математики) відбувалося у приміщенні Харківського першого вищого початкового училища; із фізики і малювання - у приміщенні приватної чоловічої гімназії «Товариства другої групи викладачів» М. М. Кноррінга; заняття із креслення і технології проходили у досить непривабливих, напівтемних приміщеннях, тимчасово обладнаних при астрономічній обсерваторії. Особливо складно проходили заняття в умовах майстерень: тут ледве розміщувалися учні 3 двох неповних недоукомплектованих класів (26 замість 40) і чотири майстра.

Через гостру потребу в облаштованих приміщеннях для проведення повноцінних занять у листопаді 1916 р. Рада Школи-майстерні звернулася до ректора Харківського університету I. В. Нетушила 3 клопотанням: просити Міністерство народної просвіти про виділення фінансування на будівництво власної оселі (проєкт майбутньої будівлі вже був розроблений університетським архітектором В.В.Величком (1864-1923) та затверджений Радою Школи) [4].

До учнів першого класу Школи приймалися лише особи, які закінчили курс двокласного початкового училища і мали, таким чином, базову підготовку з загальноосвітніх предметів. Невдовзі, через прогресуючу інфляцію, коштів, які виділялися Міністерством народної просвіти, взагалі перестало вистачати на утримання Школи.

В архіві НДІ астрономії ХНУ імені В.Н. Каразіна збереглися програми курсів для загальноосвітніх дисциплін Школи та програми робіт у майстернях [4]. 
Зокрема, для учнів першого і другого року навчання передбачалося виконання токарних і слюсарних робіт, опанування навичок ковальської і ливарної справ; учні третього і четвертого року - виконували більш кваліфіковані роботи, пов'язані 3 виготовленням гвинтів мікрометра, точних штангенциркулів, оптичних (астрономічних) труб, шліфуванням цапф для точних інструментів, вимірювальних еталонів, шліфуванням, різкою і свердлінням скла, сріблення дзеркал та ін. [4].

Влітку 1916 р. на основі головної майстерні розпочалося облаштування токарної, слюсарної, столярної, модельної і склодувної майстерень, їх обладнання відповідними інструментами, а також передбачалось укомплектування ділильними машинами. Окремо мали отримати поповнення інструментами навчальні майстерні для учнів першого та другого класів, загального інструментарію для усіх навчальних майстерень в цілому.

У перший рік діяльності майже всі роботи майстерень за обставинами військового часу були орієнтовані на виконання замовлень Харківського військово-промислового комітету. Серед них: доукомплектування снарядів 9-см бомбомета, безпосередньо ремонт бомбометів, виготовлення деталей до ручних гранат 1914-го року та перевірочного інструменту для детонаторів чавунних мін 58-мм міномета системи «Дюмезіль» [4; 8, с. 58].

За науковим напрямом діяльності Школи у майстернях було виготовлено штангель-циркуль 3 точністю відліку у 0,01 мм і реєструючий прилад до астрофотометра астрономічної обсерваторії. До кінця року було розпочато виготовлення точних рівнів, які до цього взагалі не виготовлялися у Російській імперії. У протоколах засідань Ради Школи, які збереглися в архіві НДІ астрономії ХНУ імені В.Н. Каразіна, є записи 3 наріканнями наукових співробітників щодо недоброякісності скла; як висновок - неможливість його отримання кращого гатунку. Незважаючи на це, було виготовлено 20 рівнів із ціною відліку від 1" до 10" [4].

У 1916 p. казенну стипендію у Школі отримували 15 учнів. При призначенні стипендії (становила 120 крб. на рік) Рада Школи орієнтувалася на матеріальне становище учня, ступінь його успішності як 3 теоретичних 
дисциплін, так і роботах у майстерні (відомості збиралися на основі усних опитувань учнів та їх батьків). При цьому було встановлено, що практично всі учні Школи потребують допомоги, тому у 1917 р. кількість стипендій було збільшено [4].

До літа 1916 р. Рада Школи допрацювала проєкт кошторису щорічних витрат на утримання установи на 1916-1918 рр. відповідно до зауважень Відділу навчального комітету з технічної та професійної освіти Міністерства народної просвіти, включивши додаткові позиції на придбання устаткування i збільшення щорічного фінансування закладу. Посилаючись на Статут Школи (згідно з яким до кожного класу приймаються 20 учнів), Радою передбачалося придбання кругової ділильної машини для загальної майстерні; забезпечення у достатній кількості обладнанням (придбання 15 лещат, верстата для робіт по дереву i двох верстатів для робіт по металу, десяти комплектів дрібних інструментів) для навчальної майстерні - окремо від загальної. До кошторису на щорічне утримання Школи були внесені витрати на оплату електроенергії, необхідної для живлення обладнання (1 тис. крб. щорічно); збільшення розміру стипендій для учнів (600 крб. щорічно); а також виділення додаткового фінансування на утримання помічника головного механіка (для відкриття повноцінного другого класу Школи). Загальний підрахунок щорічних витрат Школи склав 21100 карб. на рік [4].

Рада Школи, за підтримки проректора Харківського університету М. І. Палієнка (1869-1937) (на той момент в. о. ректора) звернулася до Попечителя Харківського навчального округу з проханням про клопотання перед Міністерством народної просвіти щодо затвердження виправленого кошторису.

Оскільки харківські фірми-постачальники не гарантували ані фіксування цін, ані наявності повного асортименту необхідних інструментів, ректорат Харківського університету, зі свого боку, звернувся до Відділу промислових училищ при Міністерстві народної просвіти 3 проханням про збільшення кошторису на 50-60\% від початкових розрахунків 1915 р. або про 
укомплектування Школи-майстерні через підвідомчі Міністерству народної просвіти установи [4].

Крім того, Рада Школи клопотала про збільшення кошторисної суми на будівництво власної будівлі (з 30 до 50 тис. крб.), зважаючи на високу інфляцію. Майстерня астрономічної обсерваторії Харківського університету через збільшення кількості учнів не вміщувала їх усіх, a пошуки пристосованого приміщення для оренди були вкрай ускладнені високим попитом на ринку нерухомості.

Оскільки вирішення питання про зведення власної будівлі Школимайстерні у другій половині 1916 р. з різних причин було призупинене, у січні 1917 р. проф. Л. О. Струве особисто їздив до Петрограда у Міністерство народної просвіти. Завдяки участі Г. В. Левицького йому вдалося домогтися остаточного затвердження проєкту. Як і передбачалося, Харківський університет виділив земельну ділянку на вулиці Клочківській (на межі Університетської садиби) під будівництво, але з'ясувалося, що вона за площею була меншою, ніж затверджений проєкт майбутньої Школи-майстерні [4].

Міністерство народної просвіти навіть передбачило кошти у збільшеному обсязі, ніж просила Рада Школи, але із застереженням, що Харківський університет повинен надати іншу ділянку, достатню для спорудження будівлі. Збільшення фінансування відбулося через те, що у Міністерстві народної просвіти «гармонізували» проєктну споруду Школи 3 «типовими» проєктами вже побудованих промислових училищ (звідси - збільшення його об’єму). Крім того, отримання остаточного дозволу на будівництво Школи було призупинено через відсутність окремого проєкту житлового будинку для iї навчальнодопоміжного персоналу (у поданому проєкті передбачалося виділення приміщень під квартири безпосередньо в основній споруді) [4].

Додамо, що у Петрограді проф. Л. О. Струве придбав для потреб Школимайстерні шліфувальні карборундові кола, а також замовив 600 аркушів наждачного паперу (за його інформацією, вартість матеріалів у Харкові була більшою у 20 разів, ніж у столиці) [4]. 
Після повернення до Харкова, Рада Школи терміново затвердила змінений проєкт будівлі; проф. Л. О. Струве звернувся до університетського архітектора В. В. Величка з проханням про невідкладне розроблення додаткового проєкту житлового будинку. Також завідувач Школою клопотав перед правлінням Харківського університету про виділення нової земельної ділянки під будівництво будівлі Школи-майстерні [4].

Правління університету запропонувало дві нові ділянки - біля Харківського військового шпиталю та в Університетському саду. Остання була уражена ярами і мала значний ухил. Тому Рада Школи прийняла рішення: просити Правління університету про виділення першої ділянки [4].

У 1917 р., незважаючи на початок значних соціальних потрясінь у країні, Школа-майстерня продовжувала працювати у штатному режимі, хоча і відчула вплив новацій часу. Наприклад, за пропозицією Харківського міського комітету відтепер у Школі-майстерні на видному місці був оприлюднений список військовозобов'язаних, які працюють в установі та отримали відстрочки від призову на військову службу [4].

Навесні 1917 р. Харківська міська електрична станція відмовила Школімайстерні у постачанні енергії через перехід всієї міської електричної мережі на трифазний струм. Оскільки восени Рада Школи планувала розміщення у новій оселі, а підключення змінного струму потребувало створення спеціального вводу та нових витрат, - було прийнято рішення про тимчасове використання потужностей астрономічної обсерваторії. Проф. І. С. Телетов запропонував виділити у безоплатне користування Школі-майстерні об'єм постійного струму в одну кінську силу (належав Ново-Олександрійському інституту сільського господарства та лісівництва, в якому він працював). Згідно 3 протоколом засідання Ради ця пропозиція була прийнята [4].

Досліджуючи документи архіву НДІ астрономії ХНУ імені В. Н. Каразіна, необхідно звернути увагу на низку соціально орієнтованих рішень, прийнятих Радою Школи у 1917 р. Зокрема, члени Ради ініціювали розгляд питання щодо забезпечення усіх учнів Школи лікарською допомогою. Було прийнято рішення про придбання за рахунок спеціальних коштів установи, так званих, 
«лікарняних квитків» міської Олександрівської лікарні на поточний рік (оплата лікарняного збору, який надавав право на обслуговування у лікарні протягом року без додаткової оплати) [4].

Крім того, деякі викладачі Школи запропонували втілити ідею про надання гарячих сніданків для учнів, - теж одностайно підтриману Радою. Визнаючи необхідність забезпечення такими сніданками учнів, які щодня займаються у школі по сім годин (з двогодинною перервою), а більшість 3 них мешкає далеко від Школи, Рада прийняла рішення запропонувати служителям університетських установ, розташованих в Університетському саду, готувати гарячі страви для сніданків учнів Школи-майстерні за певну винагороду, за яку сплачували безпосередньо учні. Додамо, що у подальшому принципову згоду на організацію гарячих сніданків було отримано від служителя астрономічної обсерваторії Харківського університету [4].

Влітку 1917 р. Правління університету виділяє для Школи-майстерні будівлю університетської друкарні, оскільки через peripeteia політичних настроїв пакет документів до проєкту житлового будинку не було передано до Петрограду. 3 цієї причини фінансування будівництва власної оселі Школи так i не було відкрито Міністерством. Але і його з різних бюрократичних причин Школа не змогла зайняти. Рада провела переговори з керівництвом приватної чоловічої гімназії «Товариства другої групи викладачів» М. М. Кноррінга, яка знову посприяла Школі в оренді приміщення для проведення теоретичних занять (за плату у 3 тис. крб. на рік), - з опаленням, освітленням, прислугою i квартирою для військовополоненого німецького майстра Рейніша, який працював у Школі та навчав учнів [4].

У серпні 1917 р. викладач К. Г. Гінце за станом здоров'я відмовився від викладання математики у перших та других класах; його педагогічне навантаження було передане Б. П. Герасимовичу (1889-1937). У подальшому Б. П. Герасимович - видатний астрофізик, директор Головної астрономічної обсерваторії в Пулково (1933-1937) [9].

На засіданні Ради Школи у грудні 1917 р. викладачі спільно відзначають «...вкрай неакуратне відвідування учнями уроків, а також дуже незадовільне 
виконання ними класної і домашньої роботи» [4]. До кінця року припинилося i розміщення замовлень від Харківського обласного військово-промислового комітету. Рада Школи вирішує звернутися до всіх міських навчальних закладів і установ з пропозицією про надання послуг із ремонту та виготовлення різних приладів.

Навесні 1918 р. Рада Школи звернулася до Харківського університету 3 клопотанням про збільшення суми коштів на щорічне утримання закладу до 47400 крб. на рік, мотивуючи необхідністю збільшення кількості учнів, підвищенням платні за роботу майстрів і викладачів, швидко зростаючою інфляцією, а також необхідністю внесення орендної плати за розміщення Школи. У зазначену суму також були включені три нові статті витрат: на утримання третього майстра, конторника і на виписування книг і журналів для шкільної бібліотеки. Крім того, у рапорті завідувача йшлося, що через нестачу спецкоштів наукові співробітники Школи (члени Ради) упродовж їі трирічного існування не отримували жодної винагороди [4].

Незважаючи на допомогу Харківського університету, наприкінці 1918 р. склалася вкрай важка фінансова ситуація, внаслідок якої Школа-майстерня опинилася на межі закриття. Але проф.Л.О.Струве вдалося домогтися затвердження нового кошторису. У цей час він розробляє проєкт фундаментального перетворення Школи-майстерні на Інститут точної механіки [10, с. 101].

У лютому 1919 р. після прийняття Радою Народних Комісарів УРСР постанови «Про науку i вищу школу» проф. Л.О.Струве звертається до Комісаріату народної освіти УРСР з пропозицією щодо створення Інституту точної механіки у Харкові. У пояснювальній записці до проєкту він звертає увагу посадовців на поточні геополітичні події (Першої світової війни, укладення мирного договору), які призвели до суттєвого обмеження товарообміну - від фабричних машин до дрібних вимірювальних інструментів, - що переважно вироблялися в європейських країнах [4].

Проф. Л. О. Струве наголошував, що існує можливість у найкоротші терміни налагодити постачання до промислових підприємств, технічних i 
наукових лабораторій, медичних інститутів, - необхідних приладів і інструментів. Для цього необхідно зосередити виробництво всіх видів інструментів і приладів в одному науково-технічному Інституті точної механіки, який, на його думку, став би не тільки центром постачання точних інструментів для усієї країни, а й навчальним закладом, який готував би майстрів і фахівців у різних галузях точної механіки. На думку проф. Струве, подібне «поєднання технічних i навчальних функцій в одному широко поставленому інституті вбачається, як особливо продуктивне і надзвичайно бажане» [4].

Відповідно до проєкту структура Інституту точної механіки мала складатися із п'яти великих відділів: електротехнічного, фізико-хімічного, оптичного, астрономічно-геодезичного і біологічно-медичного. Інститут очолить науковий керівник, роботу відділів - учені, фахівці у відповідній галузі, технічною частиною будуть опікуватися інженери. 3 метою економії передбачалося створення загальної майстерні для користування всіма відділами, де будуть виготовлятися металеві і дерев'яні частини інструментів, а також загальної склодувної майстерні [4].

Крім того, до структури кожного відділу входили окремі спеціальні майстерні і допоміжні сектори з лабораторно-випробувальними функціями. Для організації робіт у загальній та спеціальних майстернях передбачалося залучити професійних майстрів, під наглядом яких будуть працювати як наймані робітники (до 50 осіб), так і учні створюваного при Інституті училища, які мали складати основну частину трудового персоналу. Навчальний план училища розробляється 3 таким розрахунком, щоб учні отримували тільки загальноосвітні знання, а основна частина навчального процесу повинна зосередитися на практичних заняттях і роботах у майстернях [4].

Для оснащення Інституту необхідним інструментарієм проф. Л. О. Струве підготував детальний кошторис загальною вартістю в 1 млн. крб. (виходячи 3 цін 1915 р., збільшених у 10 разів). Також у кошторисі було враховано розроблення проєкту будівництва власної будівлі Інституту, відповідно до його структури (кошторисна вартість 75 тис. карб.) [4]. 
Оклади керівників, навчального та технічного персоналу передбачалися відповідно до постанови РНК України «Про науку та вищі школи» від 07.02.1919 р. Автором проєкту окремо наголошувалося, що «учені - завідувачі відділів, та інженери, як фахівці, - поставлені у категорію з таким розрахунком, щоб оклади їх зарплатні цілком задовольняли їхні потреби і надали можливість приділяти інституту всю свою увагу...» [4].

Пакет документів, поданий до Комісаріату народної освіти УРСР, включав проєкти кошторисів і витрат по створенню Інституту точної механіки; стислий навчальний план училища при Інституті, а також проєкт кошторису на його оснащення [4].

Відповідно до платіжної відомості Школи-майстерні, яка зберіглася в архіві НДІ астрономії ХНУ імені В. Н. Каразіна, навесні 1919 р. штат Школи складався 316 осіб: завідувача (проф. Л. О.Струве), головного механіка (B. М. Дерев'янка) і його помічника (К. М. Урсу), чотирьох майстрів (М. П. Акімова, М. О. Василенка, І. О. Мєдвєдкова, О.С. Салигіна), шести викладачів (А. І. Адріанова, О. І. Божка, О. М. Грота, П. М. Срохіна, С. Г. Саввіна, О. Л. Струве) та трьох технічних працівників. У квітні 1919 р. одинадцять учнів Школи отримували казенну стипендію [3, с. 38-39; 4].

Додамо, що у подальшому: М. П. Акімов (1901-1968) - видатний художник, режисер, публіцист, Народний артист СРСР; О. М. Грот (18801965) - всесвітньо відомий художник-живописець, засновник (спільно 3 Е. А. Штейнбергом) художньої студії у Харкові (живопис та малюнок), вихованцями якої стала низка українських художників ХX ст.; С. Г. Саввін (1861-?) - інженер-технолог, директор Харківського міського ремісничого училища, один із засновників Харківського жіночого політехнічного інституту, викладач Харківського Технологічного Інституту.

Через події громадянської війни влітку 1919 р. проєкт Інституту точної механіки не був реалізований. У жовтні Школа-майстерня точної механіки повністю припинила свою діяльність у зв'язку із від'їздом проф. Л. О. Струве 3 Харкова $[11 ; 12$, с. 41$]$. 
Таким чином, нами реконструйовані основні віхи у процесі створення та становлення як навчального закладу Школи-майстерні точної механіки при фізико-математичному факультеті Харківського університету в 1915-1919 pр. Розглянуто передумови, мету та принципи створення навчального закладу; формування тематики та напрямів навчальних програм; технічко-економічне обгрунтування діяльності Школи-майстерні; формування учбово-викладацького складу та створення інструментальної бази; з'ясовано причини припинення іiі діяльності. Архівні документи, які вперше були залучені до розгляду, дозволили відтворити хронологічну послідовність розвитку подій, пов'язаних із функціонуванням Школи-майстерні точної механіки, довести (або уточнити) деякі маловідомі факти.

Передбачається, що матеріали історико-наукового дослідження щодо створення та діяльності Школи-майстерні у 1910-х роках будуть використані у науково-дослідній роботі, присвяченій історії астрономії у Харкові першої половини XX ст.

\section{Список використаних джерел та літератури}

1. Сластенов А. И. Астрономия в Харьковском университете за 150 лет (1805-1955). Харьков: ХГУ имени А. М. Горького, 1955. 184 с.

2. 200 лет астрономии в Харьковском университете / Под. ред. проф. Ю. Г. Шкуратова. Харьков: ХНУ имени В. Н. Каразина, 2008. 632 с.

3. Балышев М. А. Отто Людвигович Струве (1897-1963). Москва: Наука, 2008. $524 \mathrm{c}$.

4. Документи поточного діловодства астрономічної обсерваторії Харківського університету (1915-1919). Архів Науково-дослідного інституту астрономії Харківського національного університету імені В. Н. Каразіна.

5. Artemenko, T. G., Balyshev, M. A., Vavilova, I. B. (2009). Struve dynasty in the history of astronomy in Ukraine. Kinematics and Physics of Celestial Bodies. 25 (3), 153-167. doi:10.3103/S0884591309030040

6. Учебные заведения: школа-мастерская точной механики. Южный край. 1915. 20 грудня. № 13108. С. 7.

7. Устав Школы-мастерской точной механики при физико-математическом факультете Императорского Харьковского университета. Харьков: Типография Б. Бенгис, 1916. 8 с.

8. Балишев М. А. Розвиток астрономії у Харкові на початку XX століття (1900-1917). Дослідження з історії і філософії науки і техніки. 2021. 30. № 1. C. 51-61. doi: 10.15421/272105

9. Балышев М. А. Звезда исключительной величины: Борис Петрович Герасимович. Universitates. Наука и Просвещение. 2004. № 4. С. 46-57. 
10. Балышев М. А. Из истории Харьковской обсерватории: биографические очерки. 200 лет астрономии в Харьковском университете. Харьков: Харьковский национальный университет, 2008. С. 99-154.

11. Балишев М. А. Астрономія в Харкові у роки громадянської війни періоду Української революції (1917-1921). Дослідження з історії і філософіï науки і техніки. 2020. 29. № 2. С. 110-118. doi: 10.15421/272027.

12. Балышев М. А. Людвиг Оттонович Струве. Заметки историка. Universitates. Наука и Просвещение. 2007. № 1. С. 34-43.

\section{References}

1. Slastenov, A. I. (1955). Astronomiya v Khar kovskom universitete za 150 let (1805-1955). [Astronomy at Kharkov University for 150 years (1805-1955)]. Kharkiv: A. M. Gorky Kharkiv State University, 184 p [in Russian].

2. Shkuratov, Y. G. (Ed.). (2008). 200 let astronomii v Harkovskom universitete [200 years of astronomy at Kharkiv University]. Kharkiv: Kharkiv National University, $632 \mathrm{p}$ [in Russian].

3. Balyshev, M. A. (2008). Otto Ludwigovich Struve (1897-1963) [Otto Ludwigovich Struve (1897-1963)]. Moscow: Nauka, 524 p [in Russian].

4. Dokumenty potochnogo dilovodstva Kharkivskoi astronomichnoi observatorii [Documents and records of the Astronomical Observatory of Kharkiv University] (1914-1919). Archive of the Institute of Astronomy V. N. Karazin Kharkiv National University [in Russian, in Ukrainian].

5. Artemenko, T. G.; Balyshev, M. A.; Vavilova, I. B. (2009). Struve dynasty in the history of astronomy in Ukraine. Kinematics and Physics of Celestial Bodies. 25 (3), 153-167 [in Ukrainian]. doi:10.3103/S0884591309030040

6. Uchebnye zavedeniya: shkola-masterskaya tochnoj mekhaniki [Educational institutions: School-workshop of precision mechanics]. South region. 1915. December 20. № 13108. P. 7 [in Russian].

7. Ustav Shkoly-masterskoj tochnoj mekhaniki pri fiziko-matematicheskom fakul'tete Imperatorskogo Har'kovskogo universiteta [Charter of the SchoolWorkshop of Precision Mechanics at the Physics and Mathematics Faculty of the Imperial Kharkov University]. Kharkov: B. Bengis Printing house, 1916. 8 p [in Russian].

8. Balyshev, M. A. (2021). Rozvitok astronomiï u Harkovi na pochatku XX stolittya (1900-1917) [Development of astronomy in Kharkiv at the beginning of the XX century (1900-1917)]. Studies in history and philosophy of science and technology. 30 (1). 51-61 [in Ukrainian]. doi: 10.15421/272105

9. Balyshev, M. A. (2004). Zvezda isklyuchitel'noj velichiny: Boris Petrovich Gerasimovich [Star of exceptional magnitude: Boris Petrovich Gerasimovich]. Universitates. Science and Education. 4. 46-57 [in Russian].

10. Balyshev, M. A. (2008). Iz istorii Kharkovskoy observatorii: biograficheskie ocherki [To the history of the Kharkiv Observatory: biographical researches]. 200 let astronomii $v$ Kharkovskom universitete [200 years of astronomy in Kharkiv University]. Kharkiv: Kharkiv National University, 632 [In Russian]. 
11. Balyshev, M. A. (2020). Astronomiya v Kharkovi u roki gromadyanskoyi vijni periodu Ukrayins koyi revolyucziyi (1917-1921) [Astronomy in Kharkiv during the Civil War period of the Ukrainian revolution (1917-1921)]. Studies in History and Philosophy of Science and Technology, 29 (2). 110-118 [In Ukrainian]. doi: $10.15421 / 272027$

12. Balyshev, M. A. (2007). Lyudvig Ottonovich Struve. Zametki istorika [Ludwig Ottonovich Struve. Notes of Historian]. Universitates. Science and Education. 1. 34-43 [in Russian].

Рецензенти:

Уткін О.I., д.і.н., професор

Аннснкова Н.Г., д.і.н., доцент

Надійшла до редакції 27.07.2021 p. 